\title{
EFFECT OF IRRIGATION WITH SALINE WATER AND SOME NATURAL ACTIVATORS ON GROWTH AND QUALITY OF THUJA ORIENTALIS PLANTS
}

\author{
Boshra A. El-Sayed, T.M. Noor El-Deen and Z.H. Riad
}

Ornamental Plants and Landscape Gardening Res. Dept., Hort. Res. Inst., ARC, Giza, Egypt.

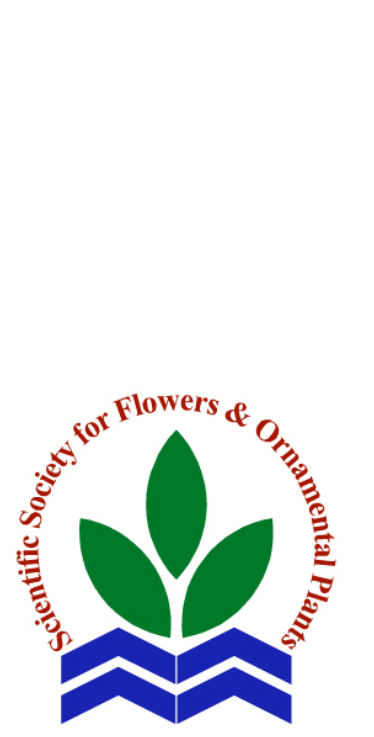

Scientific J. Flowers \& Ornamental Plants, 5(2):205-217 (2018).

Received:

26/2/2018

Accepted:

$12 / 3 / 2018$

\begin{abstract}
Two independent pot experiments were conducted under the open field at the nursery of Hort. Res. Inst., ARC., Giza, Egypt during 2016 and 2017 seasons to study the effects of irrigating with saline water prepared from $\mathrm{NaCl}$ and $\mathrm{CaCl}_{2}$ pure salts $(1: 1$, by weight) at the rates of $0,1000,3000$ and $5000 \mathrm{ppm}$ and spraying with some natural extracts i.e. Oligo- $\mathrm{X}$ (an algae extract containing immunity and internal resistant stimulants, as well as $\mathrm{N}, \mathrm{P}, \mathrm{K}, \mathrm{Fe}, \mathrm{Zn}$, $\mathrm{Mn}$ and some growth regulators) at the concentrations of $0,0.5$ and $1.0 \mathrm{ml} / \mathrm{l}$ and green tea extract at the rates of $0,0.5$ and $1.0 \mathrm{ml} / \mathrm{l}$, and their interaction on growth, quality and chemical composition of 6months-old Thuja orientalis (Platycladus orientalis) transplants cultivated in 25-cm-diameter plastic pots filled with about $3.0 \mathrm{~kg}$ of pure sand and loam (1:1, v:v) when applied six times with one month interval during the growing seasons.

The results in both seasons showed that all vegetative and root growth measurements were significantly improved by increasing the natural extract rate regardless of saline water concentration, but they were significantly decreased in response to all saline water treatments. A similar trend was also gained with regard to pigments contents (mg/l00 g f.w.), the percentage of total carbohydrates (\%), but the percentage of proline content (mg/g d.w.) was reduced with raising natural extracts, as was gradually increased with increasing salinity water.

According to these results, it could be concluded that 6-months-old transplants of Thuja orientalis could be irrigated with saline water up to $5000 \mathrm{ppm}$, especially if it was sprayed with algae extract at $1.0 \mathrm{ml} / \mathrm{l}$ which greatly improved growth and chemical constituents under salinity stress.
\end{abstract}

Key words: Thuja orientalis, natural activators, vegetative growth, chemical composition, saline water.

\section{INTRODUCTION}

Thuja orientalis (oriental arborvitae), is a tree or a shrub woody plant grown for their handsome evergreen foliage and formal habit, belongs to Fam. Pinaceae. Of easy cultivation in any soil, thriving best in full sun and propagated mainly by seeds in spring.

Several forms of $T$. orientalis are hardy as far North as Massachusetts and its favorites for formal gardens since they are all of regular symmetrical habits and are well adapted for hedges and windbreaks (Bailey, 1976). 
Salinity, however may cause some harms for plants. In this connection, Mansour and Hussein (2002) found that increasing salinity of irrigation water up to $6000 \mathrm{ppm}$ reduced the growth, as well as the chlorophylls, carotenoids and total carbohydrates contents of Tifway plants grown in sand, clay or sand + clay $(1: 1, \mathrm{v} / \mathrm{v})$. Lawn coverage, plant height and clippings fresh and dry weights were significantly reduced, especially for plants grown in sand, while those grown in clay had higher $\mathrm{Na}, \mathrm{Ca}$ and $\mathrm{Cl}$ contents. Peacock et al. (2004) mentioned that diluted sea water at the rates between 7000 and 27000 ppm resulted a great reduction in shoot weight of Tifway which reached $43 \%$, while root and crown weights were unaffected.

Similarly, were those results attained by Lee et al. (2004) on 4 Bermudagrass (Cynodon dactylon $\times$ C. transvaalensis) cultivars (Tifgreen, Tifway, Tifsport and TifEagle), Adavi et al., (2006) on Tifway and Pessarakli and Touchane (2006) who indicated that root and shoot lengths of Tifway-419 and seashore Paspalum were stimulated at the low levels of $\mathrm{NaCl}$ (5000 and $10000 \mathrm{ppm}$ ), but substantially decreased at the high levels (20000 and 30000 ppm). As the exposure time to salt stress progressed, shoot and root fresh and dry weights were more severely affected. Tifway-419 was more affected than Paspalum under any level of $\mathrm{NaCl}$ applications. Uptake of $\mathrm{Na}$ and $\mathrm{Cl}$ was increased, whereas $\mathrm{K}$ uptake was decreased.

Sadder (2013) mentioned that Atriplex halimus is a xero-halophte shrub adapted to extreme drought and salinity stresses. These characteristics are controlled by special genes which their expression was much higher at $150 \mathrm{mM}$ than at $300 \mathrm{mM} \mathrm{NaCl}$ stress level, indicating their specificity for low level salt stress. Photosynthetic activity was slightly decreased with both extended stress exposure and increased salt concentration, while total chlorophyll and proline were increased under saline stress. Similar observations were also recorded on other trees and shrubs, such as those of AlQubaie et al. (2003) on Ficus benghalensis, Tamarix articulata, Jasminum azoricum, Concarpus erectus and Ziziphus spinachristi,

Fertilization is still the most important agricultural process necessary for improving growth and quality of plants, especially natural activators such as Oligo-X, as natural preparations containing one or more of beneficial microorganisms that can release nutrients from rocks and organic matter in the soil to become available for plants, has become one of the most important requirements to protect environments from pollution, besides getting a safe and clean product. Some of the microorganisms can fix atmospheric nitrogen in a free living state, e.g. Azotobacter and Azospirillum (Darwish, 2002). Several reports stated that the natural biological balance which is disturbed by the misuse of chemical fertilizers, besides improving growth and keeping quality of the plants. In this regard, Poincelot (1993) indicated that algae extracts contain high amounts of N, P, K, Fe, Zn, Mn and Oligosaccharides, which are basically necessary for growth. Canaway (1992) found that Alginure (a seaweed extract) improved covering rate and playing of Lolium perenne cv. Loretta turf when was applied at 50, 75, 100,150 and $175 \mathrm{~g} / \mathrm{m}^{2}$ to the sand rootzone. The resilience and hardness of the plants were increased linearly with increasing Alginure rate. Poincelot (1991) postulated that cuttings of Senecio deffersii treated with ROOTS (a commercial preparation which contains kelp extracts and humic acid) at $1 \%$ as a 15-s dip showed greater rooting and produced roots 3-6 times longer than control. Similar observations were also pointed out by Poincelot (1993) on Begonia, Dahlia and Petunia, Staden et al. (1994) on Tagetes patula and Bettoni et al. (2009) on Kalanchoe blossfeldiana.

Tea is the second most consumed beverage after water and has been enjoyed around the world for centuries. Very few substances are thought to be as widely 
beneficial to a person's health with few side effects as green tea. Houston and Kimball (2013) showed that green tea is the unfermented form of tea (Camellia sinensis) and commonly used as botanical cosmeceuticals due to the antioxidant and anti-inflammatory properties found in refined tea leaves due to the presence of some compounds (phospholipids, essential fatty oils, isoflavones, proteases, phytosterols and vitamins).

Although there are scanty studies regarding the using of green tea extract in agriculture, the comprising chemical components gave it the qualifications to be used with plants. In this regard the chemical composition of tea leaves has been well documented. The main constituents of tea leaves are polyphenols (Balentine et al., 1997). The fresh tea leaves contain caffeine (approximately 3.5\% of the total dry weight), theobromine $(0.15-0.2 \%)$, theophylline (0.02-0.04\%) and other methylxanthines, lignin (6.5\%), organic acids (1.5\%), chlorophyll (0.5\%) and other pigments, theanine (4\%) and free amino acids (1$5.5 \%$ ), as well as numerous flavour compounds (Graham, 1992). In addition, a wide variety of other components exists, including, flavones, phenolic acids and depsides, carbohydrates, alkaloids, minerals, vitamins and enzymes (Chaturvedula and Prakash, 2011).

However, the current work aims to detect the beneficial effect of spraying with natural activators (Oligo- $X$ and green tea extracts) to decrease the deleterious effect of irrigated with saline water on growth performance and chemical composition of Thuja plants.

\section{MATERIALS AND METHODS}

A study was consummated under open field at the nursery of Hort. Res. Inst., Giza, Egypt during 2016 and 2017 to study the effects of irrigating with saline water and spraying with some natural extracts i.e. Oligo-X at the concentrations of $0,0.5$ and $1.0 \mathrm{ml} / \mathrm{l}$ and green tea extract at the rates of $0,0.5$ and $1.0 \mathrm{ml} / \mathrm{l}$, and their interaction on growth, quality and chemical composition of Thuja orientalis (Platycladus orientalis) transplants to determine the most effective treatment for healthy growth and high plant quality.

Six-months-old transplants Thuja orientalis (15-20 cm long with 4-5 branchs) were cultured on March, $1^{\text {st }}$ in both seasons in 25-cm-diameter plastic pots (one transplant/pot) filled with a mixture of about $3.0 \mathrm{~kg}$ of pure sand and loam $(1: 1, \mathrm{v} / \mathrm{v})$. The physical and chemical analysis of the used sand and loam are shown in Table (a).

$\mathrm{NaCl}$ salt was mixed well with $\mathrm{CaCl}_{2}$ salt at the ratio of $1: 1$, by weight. Saline water was then prepared from the salts mixture at the rates of $0,1000,3000$ and 5000 ppm. Afterwards, the plants were irrigated with $250 \mathrm{ml}$ of the previous saline water concentrations per plant.

Oligo-X (an algae extract containing immunity and internal resistant stimulants, as well as $\mathrm{N}, \mathrm{P}, \mathrm{K}, \mathrm{Fe}, \mathrm{Zn}, \mathrm{Mn}$ and some growth regulators) at the concentrations of 0 , 0.5 and $1.0 \mathrm{ml} / \mathrm{l}$. The main components of the used Oligo- $\mathrm{X}$ during the two seasons are shown in Table (b).

Green tea leaves were purchased from a local supermarket in Giza, Egypt and grounded using a blender then extracted by water according to the method described by Siripatrawan and Harte (2010). Hence, green tea water extract solution was prepared by mixing the ground tea powder in a distilled water $(1: 5 \mathrm{w} / \mathrm{w})$ controlled at $90{ }^{\circ} \mathrm{C}$ in an Erlenmeyer flask and stirred by shaking incubator for $10 \mathrm{~min}$. The water extract of green tea was filtered through Whatman No. 1 filter paper and was used at the rates of 0 , 0.5 and $1.0 \mathrm{ml} / \mathrm{l}$.

One month after planting, the transplants received the following treatments:

1. No treatment, referred to as control.

2. Oligo- $X$ at the concentrations of $0,0.5$ and $1.0 \mathrm{ml} / \mathrm{l}$.

3. Green tea extract at the rates of $0,0.5$ and $1.0 \mathrm{ml} / \mathrm{l}$. 
Boshra A. El-Sayed et al.

Table a. Some physical and chemical properties of the used sand and loam during the two seasons.

\begin{tabular}{|c|c|c|c|c|c|c|c|c|c|c|c|c|c|c|c|}
\hline \multirow{2}{*}{ 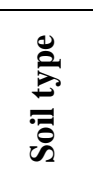 } & \multirow{2}{*}{ 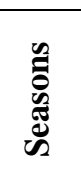 } & \multicolumn{4}{|c|}{$\begin{array}{c}\text { Particle size distribution } \\
(\%) \\
\end{array}$} & \multirow{2}{*}{ S.P } & \multirow{2}{*}{$\begin{array}{l}\text { E.C. } \\
\text { (ds/m) }\end{array}$} & \multirow{2}{*}{$\mathbf{p H}$} & \multicolumn{4}{|c|}{ Cations (meq/l) } & \multicolumn{3}{|c|}{ Anions (meq/l) } \\
\hline & & $\begin{array}{l}\text { Coarse } \\
\text { sand }\end{array}$ & $\begin{array}{l}\text { Fine } \\
\text { sand }\end{array}$ & Silt & Clay & & & & +e & $\mathrm{g}+$ & $\mathrm{Na}^{+}$ & $\mathbf{K}^{+}$ & $\mathrm{CO}_{3}^{-}$ & $\mathrm{Cl}^{-}$ & $\mathrm{SO}_{4}{ }^{--}$ \\
\hline \multirow{2}{*}{ Sandy } & 2016 & 84.76 & 6.29 & 1.50 & 7.45 & 21.87 & 3.71 & 7.80 & 19.42 & 8.33 & 7.20 & 0.75 & 1.60 & 7.80 & 26.30 \\
\hline & 2017 & 88.01 & 5.27 & 1.19 & 8.53 & 22.18 & 3.99 & 7.32 & 17.53 & 7.53 & 8.99 & 0.54 & 2.18 & 8.01 & 18.03 \\
\hline \multirow{2}{*}{ Loamy } & 2016 & 10.30 & 46.54 & 18.88 & 24.28 & 33.07 & 3.36 & 7.96 & 18.00 & 8.95 & 20.50 & 0.85 & 3.65 & 10.20 & 34.25 \\
\hline & 2017 & 10.33 & 48.19 & 18.77 & 22.71 & 33.38 & 3.35 & 7.99 & 19.03 & 8.85 & 21.55 & 0.84 & 3.02 & 10.29 & 35.68 \\
\hline
\end{tabular}

Table $b$. The main components of the used Oligo-X during the two seasons.

\begin{tabular}{llll}
\hline Component & Value & Component & Value \\
\hline Oligosaccharides & $3.0 \%$ & $\mathbf{K}_{\mathbf{2}} \mathbf{O}$ & $12.0 \%$ \\
Algaic acid & $5.0 \%$ & $\mathbf{P}_{\mathbf{2}} \mathbf{O}_{\mathbf{5}}$ & $0.5 \%$ \\
Zeatin & $0.003 \%$ & $\mathbf{N}$ & $1.0 \%$ \\
Mannitol & $0.001 \%$ & $\mathbf{Z n}$ & $0.3 \%$ \\
Cytokinin & $0.001 \%$ & $\mathbf{F e}$ & $0.2 \%$ \\
IAA & $0.0002 \%$ & $\mathbf{M n}$ & $0.1 \%$ \\
Betonin & $0.02 \%$ & & \\
\hline
\end{tabular}

4. Saline water at the rates of $0,1000,3000$ and $5000 \mathrm{ppm}$.

5. Both of each Oligo-X and green tea extracts were combined with saline water to form interaction treatments.

All treatments were repeated at one month interval, so the plants received such treatment 6 times throughout the course of the study, which was terminated on $1^{\text {st }}$ of September for both seasons.

The layout of the experiment in the two seasons was a complete randomized design (Mead et al., 1993) with three replicates, as each replicate consisted of six plants.

At the end of each season the following data were taken: plant height $(\mathrm{cm})$, number of branches/plant, number of roots/plant, root length $(\mathrm{cm})$ and as well as, fresh and dry weights of vegetative parts and roots (g). However, in fresh leaf samples taken from the middle parts of the plants, photosynthetic pigments (chlorophyll a, b and carotenoids, mg/100 g f.w.) were determined according to Moran (1982). However, in dry samples, the content of total carbohydrates percentage (Herbert et al., 1971) were measured. Furthermore, content of the free amino acid proline as $\mathrm{mg} / \mathrm{g} \mathrm{d.w}$. was assessed using the method explained by Bates et al. (1973).

Data were then tabulated and the morphological ones were undergone to analysis of variance using the program of SAS Institute Program (1994), followed by Duncan's Multiple Range Test (Duncan, 1955), to detect the significancy among the means of various treatments.

\section{RESULTS AND DISCUSSION}

\section{Effect of saline irrigation water on:}

\section{Vegetative and root growth parameters:}

From data averaged in Tables (1, 2, 3 and 4), it could be concluded that salinity of irrigation water up to $5000 \mathrm{ppm}$ had non deleterious effect on plant height $(\mathrm{cm})$, 
Table 1. Effect of irrigation with saline water and some natural activators on plant height (cm) of Thuja plants during two seasons (2016 and 2017).

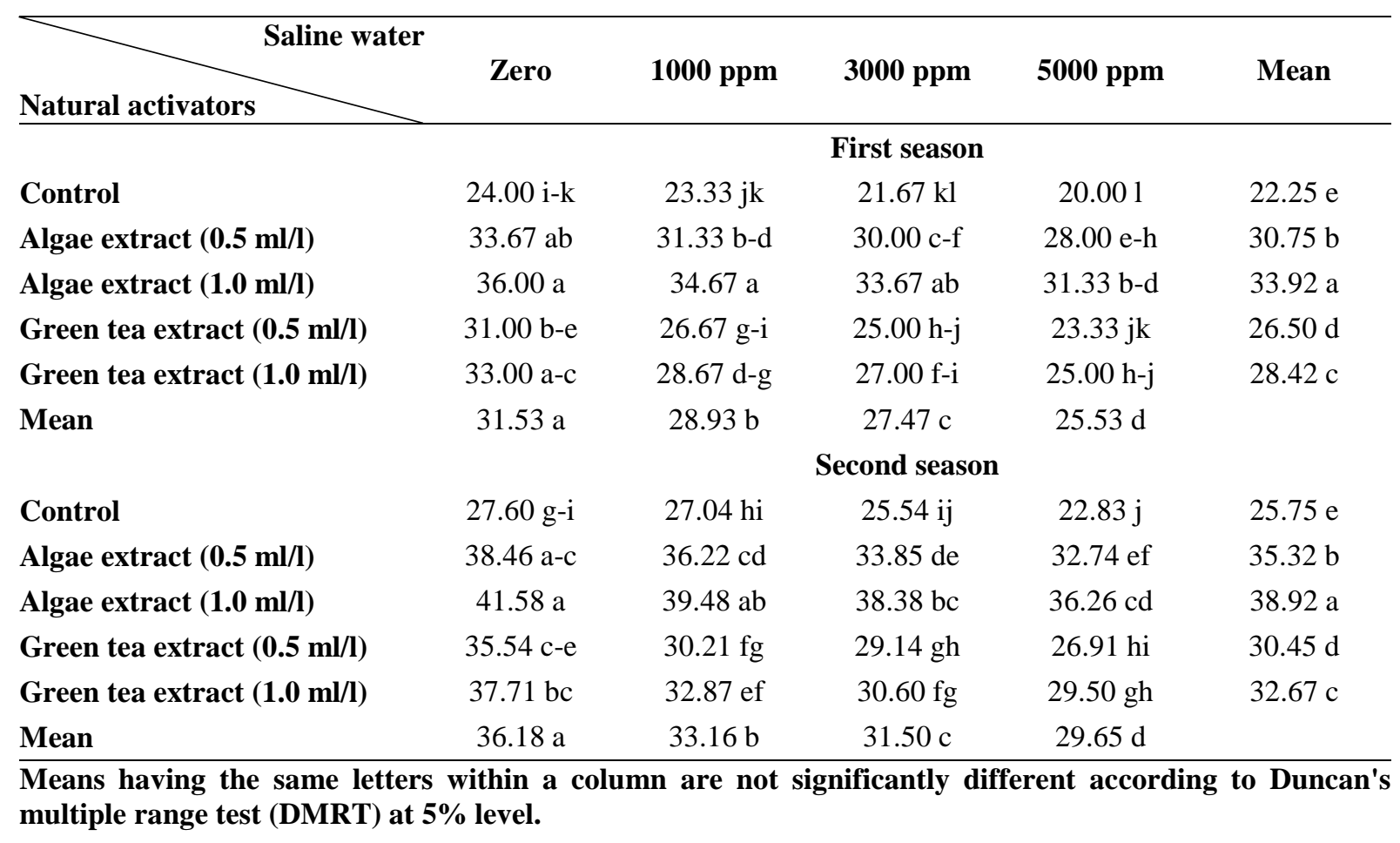

Table 2. Effect of irrigation with saline water and some natural activators on number of branches of Thuja plants during two seasons (2016 and 2017).

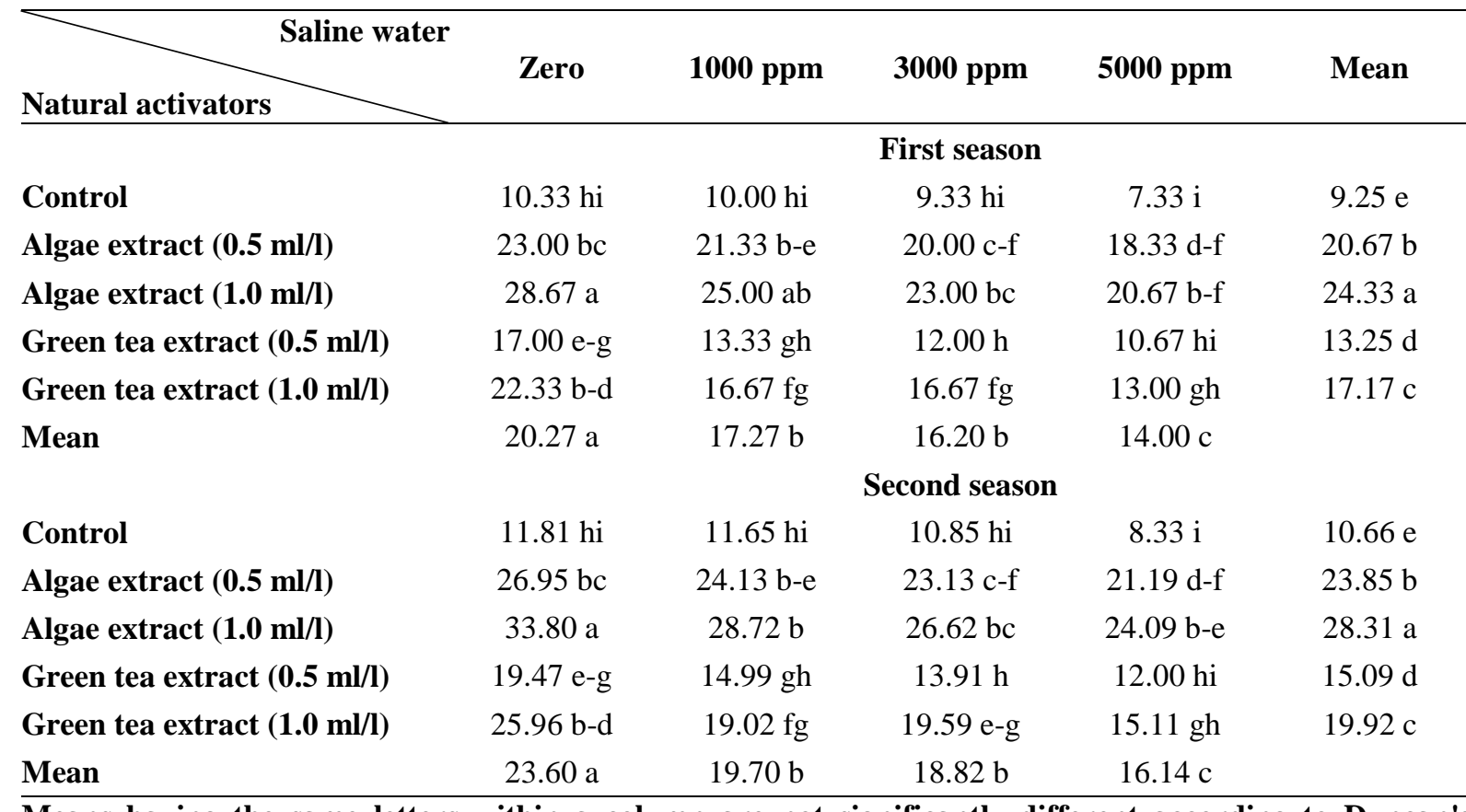

Means having the same letters within a column are not significantly different according to Duncan's multiple range test (DMRT) at 5\% level. 
Boshra A. El-Sayed et al.

Table 3. Effect of irrigation with saline water and some natural activators on number of roots of Thuja plants during two seasons (2016 and 2017).

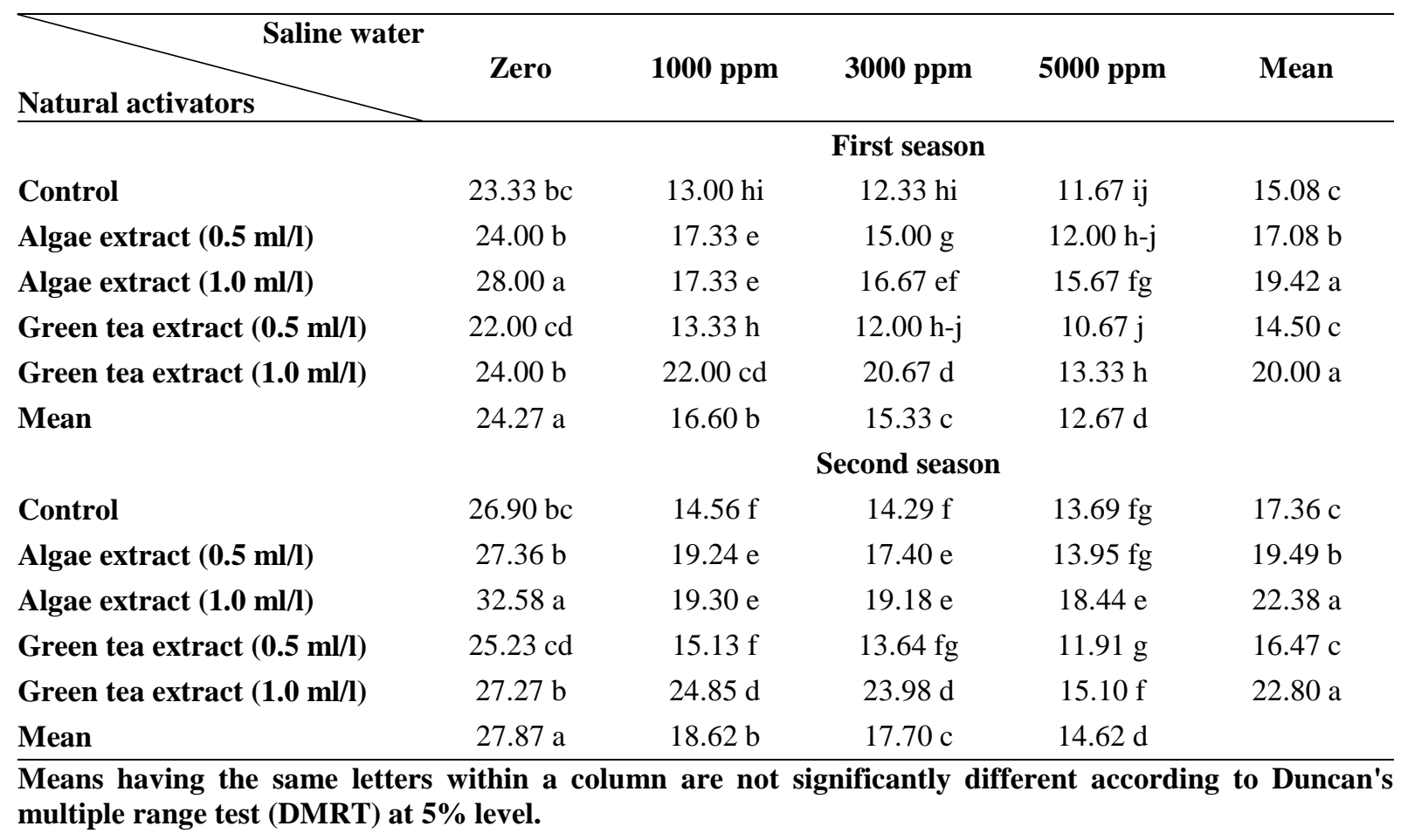

Table 4. Effect of irrigation with saline water and some natural activators on root length (cm) of Thuja plants during two seasons (2016 and 2017).

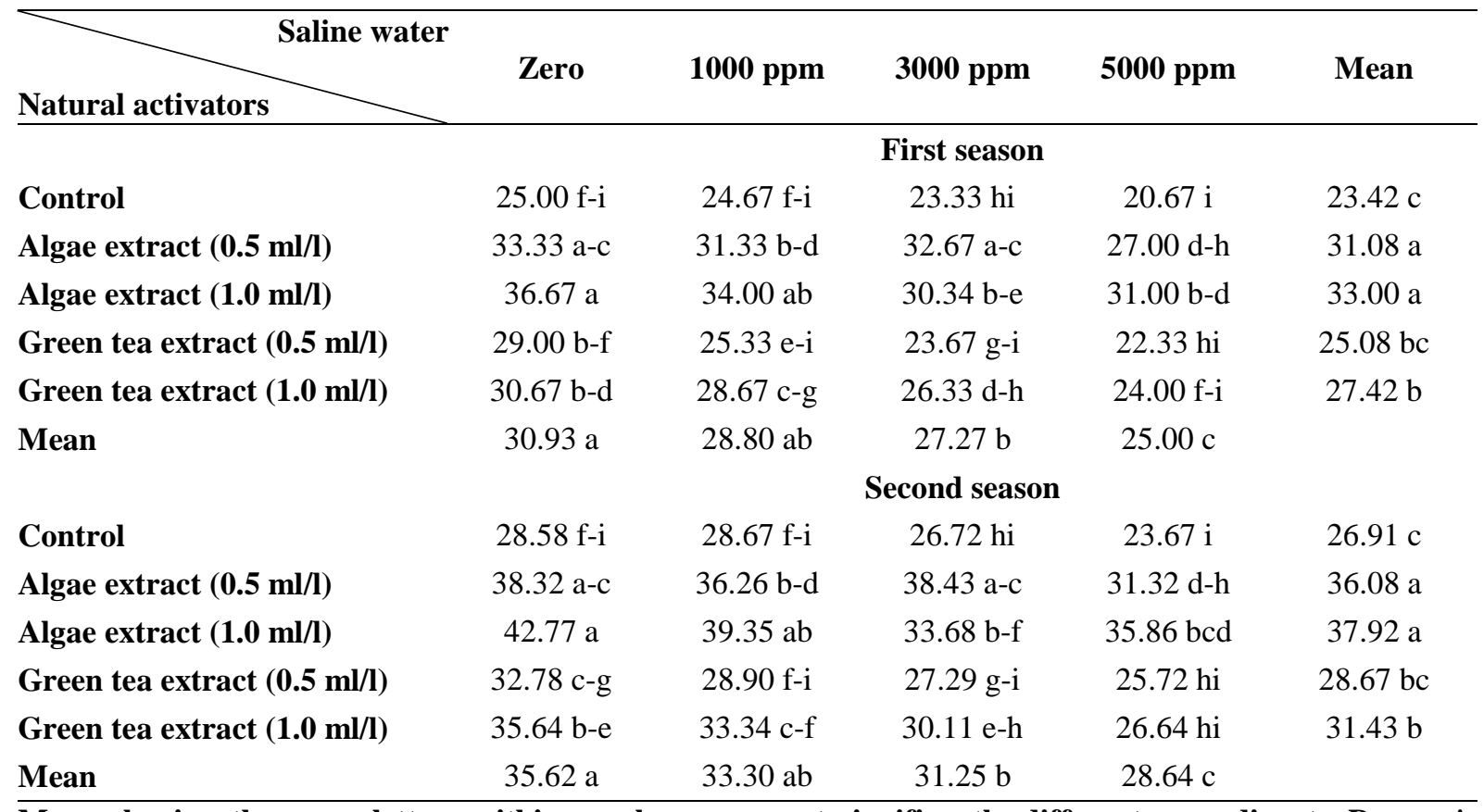

Means having the same letters within a column are not significantly different according to Duncan's multiple range test (DMRT) at 5\% level. 
number of branches, number and length of roots as the means of these parameters were closely near to those of control with nonsignificant differences in most cases of the two seasons curried, except for 1000 ppm concentration which improved vegetative growth of salinized plants with significant differences over control,

In addition, spraying with natural activators (Oligo- $\mathrm{X}$ and green tea extract) caused significant increase in all characters especially the high level of natural activators, while, spraying with natural activators (Oligo-X and tea extract) decreased the depressive effect of saline water on growth performance of plants.

From data averaged in Tables (5, 6, 7 and 8), the utmost high fresh and dry weights (g), in the two seasons were recorded by $1000 \mathrm{ppm}$ salinity treatment with spraying by Oligo-X at a concentration of $1.0 \mathrm{ml}$. The opposite was the right concerning $5000 \mathrm{ppm}$ level with spraying by Oligo-X at concentration of $1.0 \mathrm{ml}$ followed by spraying with green tea extract at the same concentration, as significantly reduced fresh and dry weights (g), in the two seasons, but they were significantly decreased in response to all saline water treatments However, noone has offered an acceptable explanation of this phenomenon, but it coincides with the results attained by Shahin (1990) on Bermudagrass and Pessarakli and Touchane (2006) who mentioned that high Na level in the outer medium enhanced cell expansion and growth of Tifway 419 and seashore Paspalum. On the other hand, the reduction of growth due to high salinity concentrations may be attributed to a decrease in all volume at a constant cell number caused by salinity (Adavi et al., 2006). Likewise, Pessarakli and Touchane (2006) postulated that mechanism of salt may result in cell division inhibitory and hence, reduces the rate of plant development. However, Jou et al. (2006) indicated that ATPase participates in the endoplasmic reticulum Golgi mediated protein sorting machinery for both housekeeping function and compartmentalization of excess $\mathrm{Na}^{+}$under high salinity. On the same line, were those results revealed by Shahin (1990) on ryegrass, Lee et al. (2004) on 4 Bermudagrass cultivars, Adavi et al. (2006) and Abdel Fattah et al. (2008) on Tifway.

\section{Chemical composition:}

Data presented in Tables (9 and 10) exhibit that pigments content (chlorophyll a, b and carotenoids as mg/100 g f.w. ) and total carbohydrates (\%) in the leaves of Thuja plants were gradually decreased as a result of irrigation with various levels of saline water, but progressively increased with increasing Oligo-X followed by green tea extract rate. As for proline content (mg/g d.w.) in the leaves, it was cumulatively increased with raising either salinity level only or with natural activators. So, the highest record of this trait was registered by plants treated with the highest levels of both salinity (5000 ppm), while spraying by natural activators only were gradually decreased as a result. It was suggested that accumulation of some amino acids and amides in the leaves of salinity-stressed plants may be due to de novo synthesis and not to the result of degradation (Gilbert et al., 1998).

Such results, in general showed a similar trend to those of Pessarakli and Touchane (2006) on Tifway-419 and seashore Paspalum and Hunter and Butler (2005) on Agrostis stolonifera.

From the previous findings, it could be concluded that Thuja plants can relatively tolerate irrigation with saline water up to $5000 \mathrm{ppm}$, especially if treated with natural activators (Oligo- $X$ and extract of tea) to decrease the deleterious effect of irrigation with saline water on growth performance and chemical composition of Thuja plants. 
Boshra A. El-Sayed et al.

Table 5. Effect of irrigation with saline water and some natural activators on vegetative parts fresh weight (g) of Thuja plants during two seasons (2016 and 2017).

\begin{tabular}{|c|c|c|c|c|c|}
\hline$\overbrace{\text { Natural activators }}^{\text {Saline } w}$ & Zero & 1000 ppm & 3000 ppm & 5000 ppm & Mean \\
\hline & \multicolumn{5}{|c|}{ First season } \\
\hline Control & $33.50 \mathrm{i}$ & $30.58 \mathrm{ij}$ & $31.05 \mathrm{i}$ & $23.71 \mathrm{j}$ & $29.71 \mathrm{e}$ \\
\hline Algae extract (0.5 ml/l) & 58.71 bc & 58.02 b-d & $53.47 \mathrm{~cd}$ & $51.41 \mathrm{~d}-\mathrm{f}$ & $55.40 \mathrm{~b}$ \\
\hline Algae extract $(1.0 \mathrm{ml} / \mathrm{l})$ & $71.10 \mathrm{a}$ & $63.14 \mathrm{~b}$ & $56.11 \mathrm{~cd}$ & 52.61 c-e & $60.74 \mathrm{a}$ \\
\hline Green tea extract $(0.5 \mathrm{ml} / \mathrm{l})$ & $42.31 \mathrm{gh}$ & 37.25 hi & 36.77 hi & $32.61 \mathrm{i}$ & $37.23 \mathrm{~d}$ \\
\hline Green tea extract $(1.0 \mathrm{ml} / \mathrm{l})$ & 52.52 c-e & $46.28 \mathrm{e}-\mathrm{g}$ & $44.58 \mathrm{fg}$ & $40.41 \mathrm{gh}$ & $45.94 \mathrm{c}$ \\
\hline \multirow[t]{2}{*}{ Mean } & $51.63 \mathrm{a}$ & $47.05 \mathrm{~b}$ & $44.40 \mathrm{~b}$ & $40.15 \mathrm{c}$ & \\
\hline & \multicolumn{5}{|c|}{ Second season } \\
\hline Control & $39.67 \mathrm{j}-\mathrm{l}$ & $35.06 \mathrm{~lm}$ & $35.90 \mathrm{kl}$ & $27.41 \mathrm{~m}$ & $34.51 \mathrm{e}$ \\
\hline Algae extract $(0.5 \mathrm{ml} / \mathrm{l})$ & $67.19 \mathrm{~b}-\mathrm{d}$ & $67.89 \mathrm{bc}$ & 61.85 c-e & $59.24 \mathrm{ef}$ & $64.04 \mathrm{~b}$ \\
\hline Algae extract $(1.0 \mathrm{ml} / \mathrm{l})$ & 80.81 a & $72.56 \mathrm{~b}$ & 63.92 c-e & 58.74 e-g & $69.01 \mathrm{a}$ \\
\hline Green tea extract $(0.5 \mathrm{ml} / \mathrm{l})$ & $49.23 \mathrm{hi}$ & 42.79 i-k & $40.88 \mathrm{j}-1$ & $37.45 \mathrm{kl}$ & $42.59 \mathrm{~d}$ \\
\hline Green tea extract $(1.0 \mathrm{ml} / \mathrm{l})$ & 59.79 d-f & $52.32 \mathrm{f}-\mathrm{h}$ & $51.28 \mathrm{gh}$ & 46.85 h-j & $52.56 \mathrm{c}$ \\
\hline Mean & $59.34 \mathrm{a}$ & $54.12 \mathrm{~b}$ & $50.77 \mathrm{~b}$ & $45.94 \mathrm{c}$ & \\
\hline
\end{tabular}

Table 6. Effect of irrigation with saline water and some natural activators on vegetative parts dry weight (g) of Thuja plants during two seasons (2016 and 2017).

\begin{tabular}{|c|c|c|c|c|c|}
\hline $\mathrm{P}_{\text {Natural activators }}^{\text {Saline w }}$ & Zero & 1000 ppm & 3000 ppm & 5000 ppm & Mean \\
\hline & \multicolumn{5}{|c|}{ First season } \\
\hline Control & $15.50 \mathrm{~h}-\mathrm{j}$ & $14.40 \mathrm{i}-\mathrm{k}$ & $14.53 \mathrm{i}-\mathrm{k}$ & $11.38 \mathrm{k}$ & $13.95 \mathrm{~d}$ \\
\hline Algae extract (0.5 ml/l) & $30.25 \mathrm{ab}$ & $27.17 \mathrm{~b}-\mathrm{d}$ & 26.32 b-e & $23.81 \mathrm{~d}-\mathrm{f}$ & $26.89 \mathrm{a}$ \\
\hline Algae extract (1.0 ml/l) & 32.62 a & 29.45 a-c & 25.82 c-e & $23.02 \mathrm{ef}$ & $27.73 \mathrm{a}$ \\
\hline Green tea extract $(0.5 \mathrm{ml} / \mathrm{l})$ & $18.28 \mathrm{~g}-\mathrm{i}$ & 17.16 g-j & 17.76 g-j & $13.95 \mathrm{jk}$ & $16.79 \mathrm{c}$ \\
\hline Green tea extract $(1.0 \mathrm{ml} / \mathrm{l})$ & $23.78 \mathrm{~d}-\mathrm{f}$ & 23.98 d-f & $20.43 \mathrm{fg}$ & 18.94 gh & $21.78 \mathrm{~b}$ \\
\hline \multirow[t]{2}{*}{ Mean } & 24.08 a & $22.43 \mathrm{ab}$ & $20.97 \mathrm{~b}$ & 18.22 c & \\
\hline & \multicolumn{5}{|c|}{ Second season } \\
\hline Control & $17.99 \mathrm{f}-\mathrm{h}$ & 15.96 hi & 16.49 g-i & $13.17 \mathrm{i}$ & $15.90 \mathrm{~d}$ \\
\hline Algae extract (0.5 ml/l) & $35.60 \mathrm{ab}$ & 30.96 bc & 29.03 c & 27.18 cd & 30.69 a \\
\hline Algae extract (1.0 ml/l) & $36.86 \mathrm{a}$ & $34.84 \mathrm{ab}$ & 29.47 c & $27.07 \mathrm{~cd}$ & $32.06 \mathrm{a}$ \\
\hline Green tea extract $(0.5 \mathrm{ml} / \mathrm{l})$ & 21.33 ef & 19.55 e-h & 20.56 e-h & $15.90 \mathrm{hi}$ & $19.34 \mathrm{c}$ \\
\hline Green tea extract $(1.0 \mathrm{ml} / \mathrm{l})$ & $27.50 \mathrm{~cd}$ & $28.38 \mathrm{~cd}$ & 23.92 de & 21.18 e-g & $25.24 \mathrm{~b}$ \\
\hline Mean & $27.86 \mathrm{a}$ & $25.94 \mathrm{ab}$ & $23.89 \mathrm{~b}$ & $20.90 \mathrm{c}$ & \\
\hline
\end{tabular}

Means having the same letters within a column are not significantly different according to Duncan's multiple range test (DMRT) at 5\% level. 
Table 7. Effect of irrigation with saline water and some natural activators on roots fresh weight (g) of Thuja plants during two seasons (2016 and 2017).

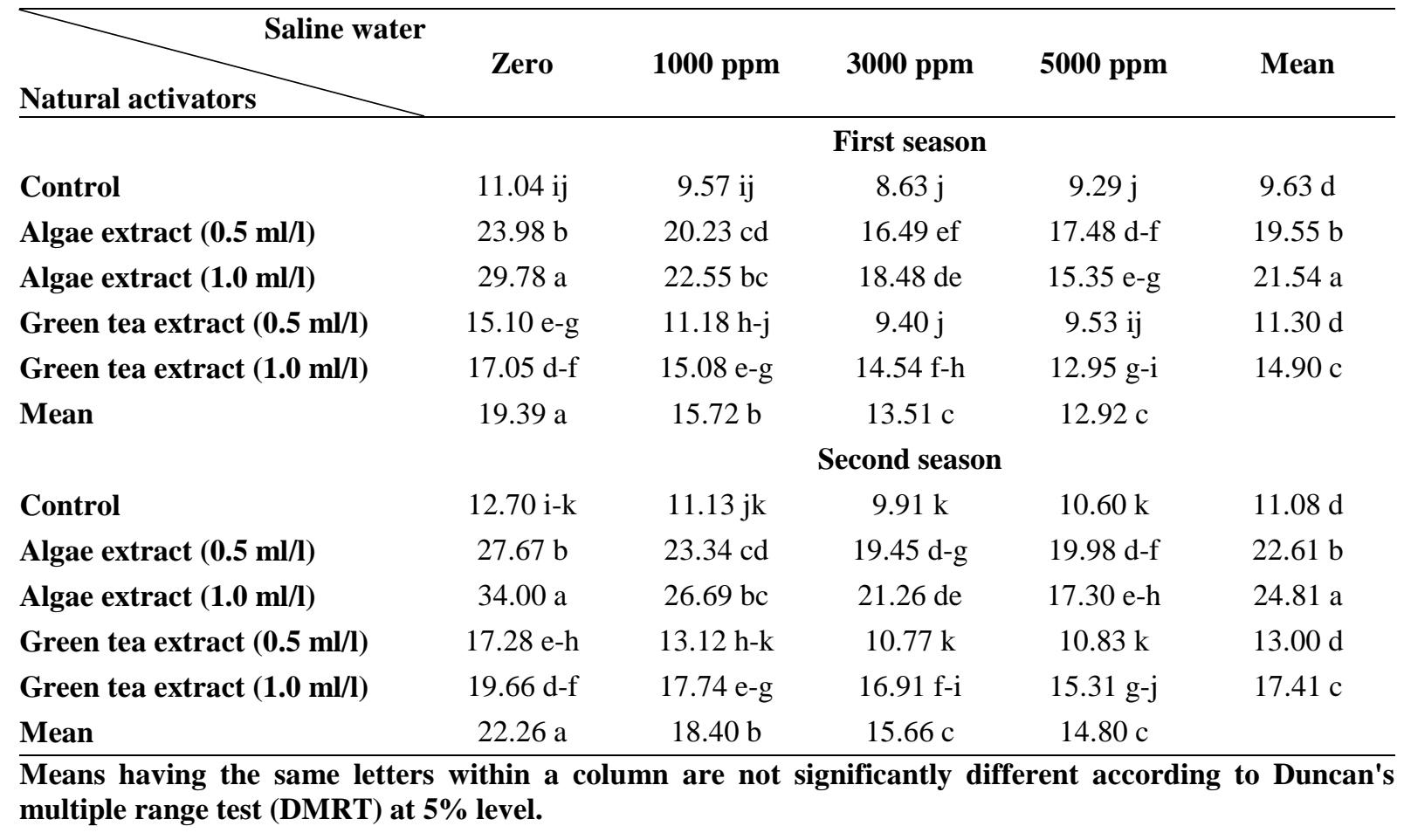

Table 8. Effect of irrigation with saline water and some natural activators on roots dry weight (g) of Thuja plants during two seasons (2016 and 2017).

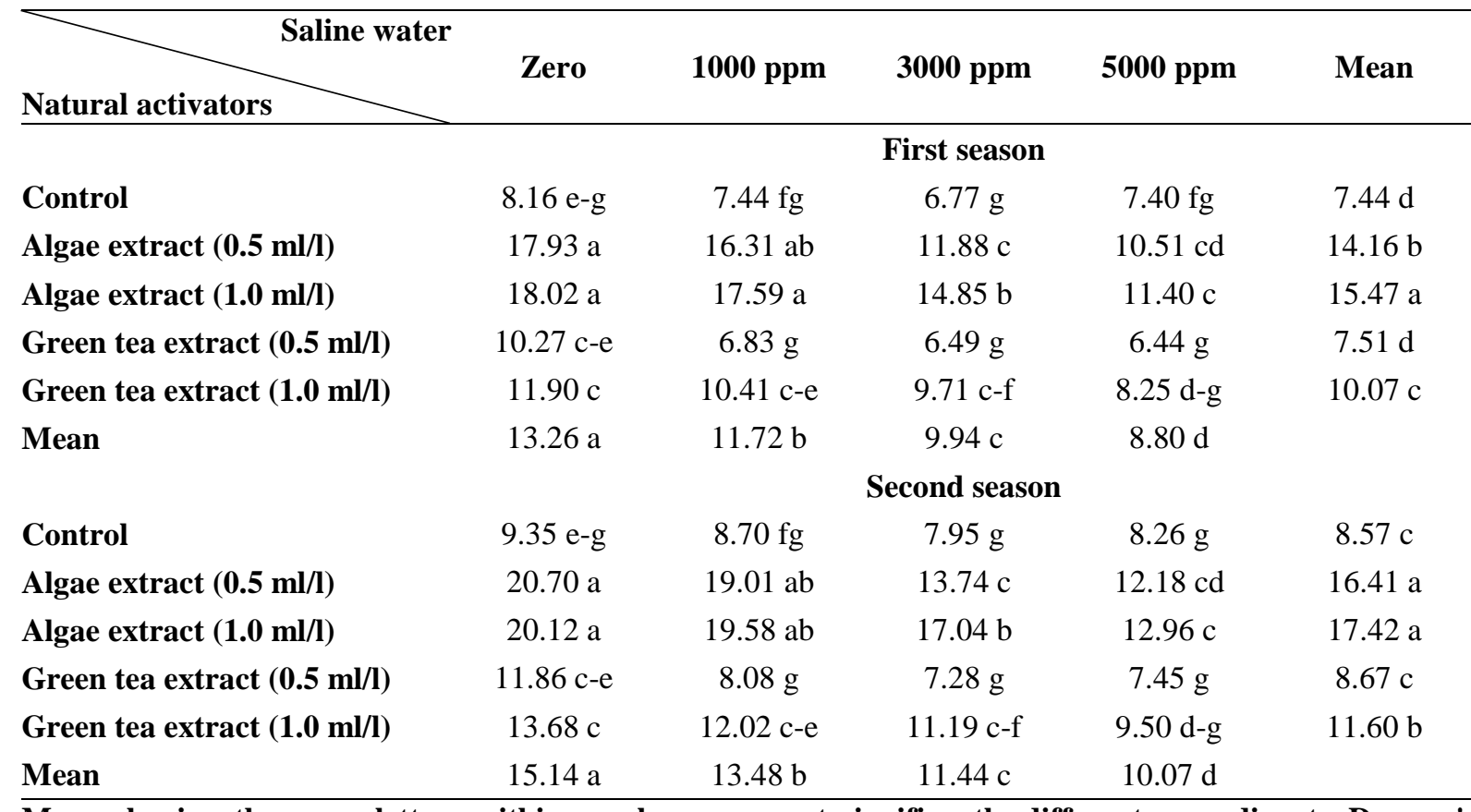

Means having the same letters within a column are not significantly different according to Duncan's multiple range test (DMRT) at $5 \%$ level. 
Boshra A. El-Sayed et al.

Table 9. Effect of irrigation with saline water and some natural activators on pigments content in the leaves of Thuja plants during the second season (2017).

\begin{tabular}{|c|c|c|c|c|c|}
\hline$\underbrace{\text { Saline }}_{\text {Natural activators }}$ & Zero & 1000 ppm & 3000 ppm & 5000 ppm & Mean \\
\hline & \multicolumn{5}{|c|}{ Chlorophyll a “mg/100 g f.w.” } \\
\hline Control & $0.777 \mathrm{~cd}$ & $0.713 \mathrm{f}$ & $0.586 \mathrm{hi}$ & $0.498 \mathrm{j}$ & $0.644 \mathrm{~d}$ \\
\hline Algae extract $(0.5 \mathrm{ml} / \mathrm{l})$ & $0.811 b$ & 0.782 bc & $0.661 \mathrm{~g}$ & $0.613 \mathrm{~h}$ & $0.717 \mathrm{~b}$ \\
\hline Algae extract (1.0 ml/l) & $0.877 \mathrm{a}$ & 0.790 bc & $0.784 \mathrm{bc}$ & 0.720 ef & 0.793 a \\
\hline Green tea extract $(0.5 \mathrm{ml} / \mathrm{l})$ & 0.792 bc & 0.725 ef & 0.604 hi & $0.576 \mathrm{i}$ & $0.674 \mathrm{c}$ \\
\hline Green tea extract $(1.0 \mathrm{ml} / \mathrm{l})$ & 0.810 bc & 0.747 de & $0.651 \mathrm{~g}$ & 0.607 hi & $0.704 \mathrm{~b}$ \\
\hline \multirow[t]{2}{*}{ Mean } & $0.813 \mathrm{a}$ & $0.752 \mathrm{~b}$ & $0.657 \mathrm{c}$ & $0.603 \mathrm{~d}$ & \\
\hline & \multicolumn{5}{|c|}{ Chlorophyll b “mg/100 g f.w.” } \\
\hline Control & 0.623 b-e & $0.606 \mathrm{~d}-\mathrm{g}$ & $0.574 \mathrm{gh}$ & $0.539 \mathrm{i}$ & $0.586 \mathrm{~d}$ \\
\hline Algae extract $(0.5 \mathrm{ml} / \mathrm{l})$ & 0.658 a & $0.630 \mathrm{a}-\mathrm{d}$ & $0.626 \mathrm{a}-\mathrm{d}$ & $0.575 \mathrm{f}-\mathrm{h}$ & $0.622 \mathrm{~b}$ \\
\hline Algae extract $(1.0 \mathrm{ml} / \mathrm{l})$ & 0.659 a & $0.646 \mathrm{a}-\mathrm{c}$ & $0.644 \mathrm{a}-\mathrm{c}$ & 0.613 с-е & 0.641 a \\
\hline Green tea extract $(0.5 \mathrm{ml} / \mathrm{l})$ & $0.638 \mathrm{a}-\mathrm{d}$ & 0.624 b-e & $0.592 \mathrm{e}-\mathrm{h}$ & 0.566 hi & 0.605 c \\
\hline Green tea extract $(1.0 \mathrm{ml} / \mathrm{l})$ & $0.656 \mathrm{ab}$ & 0.629 a-d & $0.607 \mathrm{~d}-\mathrm{f}$ & $0.569 \mathrm{hi}$ & 0.615 bc \\
\hline \multirow[t]{2}{*}{ Mean } & $0.647 \mathrm{a}$ & $0.627 \mathrm{~b}$ & 0.609 c & $0.573 \mathrm{~d}$ & \\
\hline & \multicolumn{5}{|c|}{ Carotenoids “mg/100 g f.w.” } \\
\hline Control & $0.076 \mathrm{ab}$ & $0.073 \mathrm{ab}$ & $0.068 \mathrm{ab}$ & $0.057 \mathrm{~b}$ & 0.069 a \\
\hline Algae extract $(0.5 \mathrm{ml} / \mathrm{l})$ & $0.092 \mathrm{a}$ & $0.083 \mathrm{ab}$ & $0.073 \mathrm{ab}$ & $0.067 \mathrm{ab}$ & $0.079 \mathrm{a}$ \\
\hline Algae extract $(1.0 \mathrm{ml} / \mathrm{l})$ & 0.093 a & $0.084 \mathrm{ab}$ & $0.075 \mathrm{ab}$ & $0.069 \mathrm{ab}$ & 0.080 a \\
\hline Green tea extract $(0.5 \mathrm{ml} / \mathrm{l})$ & $0.082 \mathrm{ab}$ & $0.077 \mathrm{ab}$ & $0.071 \mathrm{ab}$ & $0.059 \mathrm{~b}$ & $0.072 \mathrm{a}$ \\
\hline Green tea extract $(1.0 \mathrm{ml} / \mathrm{l})$ & $0.086 \mathrm{ab}$ & $0.081 \mathrm{ab}$ & $0.072 \mathrm{ab}$ & $0.065 \mathrm{ab}$ & $0.076 \mathrm{a}$ \\
\hline Mean & $0.086 \mathrm{a}$ & 0.079 a & $0.072 \mathrm{ab}$ & $0.063 \mathrm{~b}$ & \\
\hline
\end{tabular}

Means having the same letters within a column are not significantly different according to Duncan's multiple range test (DMRT) at $5 \%$ level. 
Table 10. Effect of irrigation with saline water and some natural activators on total carbohydrates and proline concentrations in the leaves of Thuja plants during the second season (2017).

\begin{tabular}{|c|c|c|c|c|c|}
\hline$\underbrace{\text { Saline }}_{\text {Natural activators }}$ & Zero & 1000 ppm & 3000 ppm & $5000 \mathrm{ppm}$ & Mean \\
\hline & \multicolumn{5}{|c|}{ Total carbohydrates (\%) } \\
\hline Control & $14.210 \mathrm{f}$ & $11.370 \mathrm{ij}$ & $10.840 \mathrm{jk}$ & $7.200 \mathrm{~m}$ & $10.900 \mathrm{e}$ \\
\hline Algae extract $(0.5 \mathrm{ml} / \mathrm{l})$ & $21.500 \mathrm{~b}$ & $18.310 \mathrm{c}$ & $12.810 \mathrm{~g}$ & 11.580 hi & $16.050 \mathrm{~b}$ \\
\hline Algae extract $(1.0 \mathrm{ml} / \mathrm{l})$ & 22.430 a & $18.770 \mathrm{c}$ & $16.210 \mathrm{~d}$ & 11.620 hi & $17.260 \mathrm{a}$ \\
\hline Green tea extract $(0.5 \mathrm{ml} / \mathrm{l})$ & $15.840 \mathrm{~d}$ & $12.920 \mathrm{~g}$ & $12.070 \mathrm{~h}$ & 8.7601 & $12.400 \mathrm{~d}$ \\
\hline Green tea extract $(1.0 \mathrm{ml} / \mathrm{l})$ & 18.620 c & $15.080 \mathrm{e}$ & $12.680 \mathrm{~g}$ & $10.680 \mathrm{k}$ & $14.260 \mathrm{c}$ \\
\hline \multirow[t]{2}{*}{ Mean } & 18.520 a & $15.290 \mathrm{~b}$ & 12.920 c & $9.968 \mathrm{~d}$ & \\
\hline & \multicolumn{5}{|c|}{ Proline contents (mg/g d.w.) } \\
\hline Control & 0.137 gh & 0.153 e-g & $0.312 \mathrm{a}$ & 0.342 a & $0.236 \mathrm{a}$ \\
\hline Algae extract (0.5 ml/l) & 0.114 h-j & $0.140 \mathrm{gh}$ & 0.183 c-e & 0.186 c-e & $0.156 \mathrm{c}$ \\
\hline Algae extract $(1.0 \mathrm{ml} / \mathrm{l})$ & $0.083 \mathrm{j}$ & $0.100 \mathrm{ij}$ & $0.173 \mathrm{~d}-\mathrm{f}$ & 0.184 c-e & $0.135 \mathrm{~d}$ \\
\hline Green tea extract $(0.5 \mathrm{ml} / \mathrm{l})$ & 0.132 g-i & $0.149 \mathrm{fg}$ & $0.210 \mathrm{bc}$ & $0.226 \mathrm{~b}$ & $0.179 \mathrm{~b}$ \\
\hline Green tea extract $(1.0 \mathrm{ml} / \mathrm{l})$ & 0.132 g-i & $0.145 \mathrm{f}-\mathrm{h}$ & $0.187 \mathrm{~cd}$ & $0.189 \mathrm{~cd}$ & $0.163 \mathrm{bc}$ \\
\hline Mean & $0.120 \mathrm{c}$ & $0.138 \mathrm{~b}$ & 0.213 a & 0.225 a & \\
\hline
\end{tabular}

Means having the same letters within a column are not significantly different according to Duncan's multiple range test (DMRT) at $5 \%$ level.

\section{REFERENCES}

Abdel-Fattah, Gehan H.; El-Sayed Boshra, A. and Shahin, S.M. (2008). The role of humic acid in reducing the harmful effect of irrigation with saline water on Tifway turf. J. Biol. Chem. \& Environ. Sci., 3(1):75-89.

Adavi, Z.; Razmjoo, K. and Mobli, M. (2006). Salinity tolerance of Bermuda grass cultivars and shoot $\mathrm{Na}, \mathrm{K}$ and $\mathrm{Cl}$ contents under a high saline environment. J. Hort. \& Biotech., 81(6):1074-78.

Al-Qubaie, A.I.; Shahin, S.M. and AlToukhy, A.A. (2003). Response of some ornamental trees and shrubs to irrigation intervals. Egypt. J. Appl. Sci., 18(8B):602-617.

Bailey, L.H. (1976). Hortus Third, Macmillan Publishing Co., Inc., 866 Third Avenue, New York, N.Y. 10022, 1290 pp.
Balentine, D.A.; Wiseman, S.A. and Bouwens, L.C. (1997). The chemistry of tea flavonoids. Critical Reviews in Food Science and Nutrition, 37:693-704.

Bates, L.S.; Waldern, R.P. and Tear, I.D. (1973). Rapid determination of free proline under water stress studies. Plant and Soil., 39:205-207.

Bettoni, M.M.; Gumpl, E.K.; Cuquel, F.L. and Mogor, A.F. (2009). Response of kalanchoe plants to plant growth regulators. Revista Brasileira de Hort. Ornam., 15(2):153-157.

Canaway, P.M. (1992). The effects of two rootzone amendments on cover and playing quality of a sand profile construction for football. Journal of the Sports Turf Res. Inst., 68: 50-61.

Chaturvedula, V.S.P. and Prakash, I. (2011). The aroma, taste, color and bioactive constituents of tea. Journal of Medicinal Plants Research, 5:2110-2124. 
Darwish, F.M. (2002). Effect of Different Fertilizer Sources and Levels on Growth, Yield and Quality of Tomato. Ph.D. Thesis, Fac. Agric., Cairo Univ., Egypt.

Duncan, D.B. (1955). Multiple range and multiple F-tests. J. Biometrics, 11:1-42.

Gilbert, G.A.; Gadushi, M.V.; Wilson, C. and Madore, M.A. (1998). Amino acid accumulation in sink and source tissues of Coleus blumei Benth. during salinity stress. J. Experimental Botany, 49(3/8):107-114.

Graham, H.N. (1992). Green tea composition, consumption, and polyphenol chemistry. Preventive Medicine, 21:334-350.

Herbert, D.; Phipps, P.J. and Strange, R.E. (1971). Determination of total carbohydrates, Methods in Microbiology, 5(8):290-344.

Houston, N. and Kimball, A.B. (2013). Green Tea Extract: Cosmeceuticals and Cosmetic Practice. John Wiley \& Sons, 122-132.

Hunter, A. and Butler, T. (2005). Effect of humic acid on growth and development of Agrostis stolonifera grass in a sandbased root zone. Inter. Turfgrass Soci. Res. J., 10:937-943.

Jou, Y.; Chiang, C.; Jauh, G. and Yen, H.C. (2006). Functional characterization of ice plant SDKI, an AAA-type ATPase associated with the endoplasmic reticulum-Golgi network, and its role in adaptation to salt stress. Plant Physiol., 141(1):135-146.

Lee, G.; Carrow, R.N. and Duncan, R.R. (2004). Salinity tolerance of selected seashore Paspalums and Bermudagrasses: root and verdure responses and criteria. HortScience, 39(5):1143-47.

Mansour, H.A. and Hussein, M.M. (2002). Tolerance of three turfgrasses grown in three types of soil to irrigation water salinity. Bull. Fac. Agric., Cairo Univ., 53(2):235-264.

Mead, R.; Curnow, R.N. and Harted, A.M. (1993). Statistical Methods in Agriculture and Experimental Biology. $2^{\text {nd }}$ Ed., Chapman \& Hall Ltd., London, 335 pp.

Moran, R. (1982). Formula for determination of chlorophyllous pigment extracted with N-N- dimethyl formamide. Plant Physiol., 69:1376-81.

Peacock, C.H.; Lee, D.J.; Reynolds, W.C.; Gregg, J.P. and Cooper, R.J. (2004). Effects of salinity on six Bermudagrass turf cultivars. Acta Hort., 661:193-197.

Pessarakli, M. and Touchane, H. (2006). Growth responses of Bermudagrass and seashore Paspalum under various levels of sodium chloride stress. J. Food, Agric. and Environ., 4(3/4):240-243.

Poincelat, R.P. (1991). Seaweed/humus extracts as biostimulants for succulent propagation. Cactus and Succulent Journal, 63(4):180-181.

Poincelat, R.P. (1993). The use of a commercial organic biostimulant for bedding plant production. Journal of Sustainable Agriculture, 3(2):99-110.

Sadder, M.T. (2013). Gene expression and physiological analysis of Atriplex halimus L. under salt stress. Australian J. of Crop. Sci., 7(1):112-118.

SAS Institute (1994). SAS/STAT User's Guide: Statistics. Vers. 6.04, $4^{\text {th }}$ Ed., SAS Institute Inc., Cary, N.C., USA.

Shahin, S.M. (1990). Effect of Salinity on Growth and Constituents of Some Turfgrass Species. M.Sc. Thesis, Fac. Agric., Cairo Univ.

Siripatrawan, U. and Harte, B.R. (2010). Physical properties and antioxidant activity of an active film from chitosan incorporated with green tea extract. Food Hydrocolloids, 24(8):770-775. 
Staden, J.; Upfold, S.J. and Drewes, F.E. (1994). Effect of seaweed concentrate on growth and development of marigold
(Tagetes patula). Journal of Applied Phycology, 6(4):427-428.

\section{تأثير الرى بالماء المالح وبعض المنشطات الطبيعية على نمو وجودة نباتات التويا}

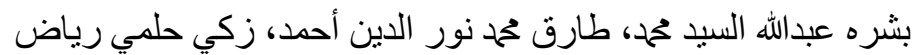

$$
\begin{aligned}
& \text { قسم بحوث الزينة وتنسيق الحدائق، معهد بحوث البساتين، مركز البحوث النين الزر اعية، الجيزة، مصر. }
\end{aligned}
$$

أجريت تجربة أصص بالحقل المفتوح بمشتل معهد بحوث البساتين، مركز البحوث الزر اعية، الجيزة، مصر خلال

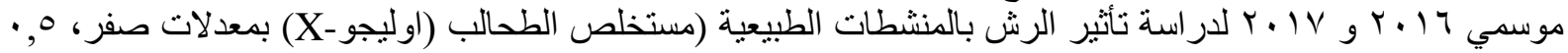

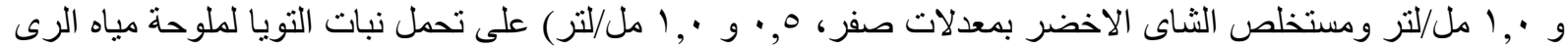

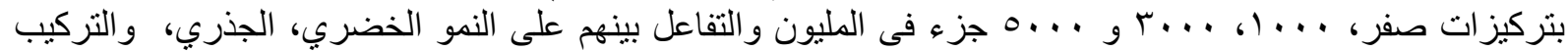

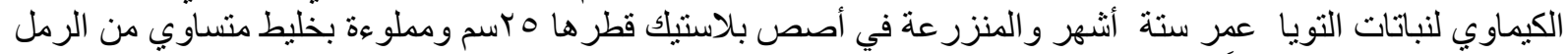

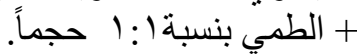

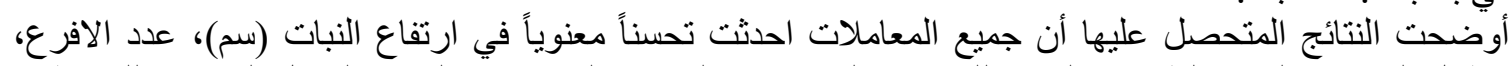

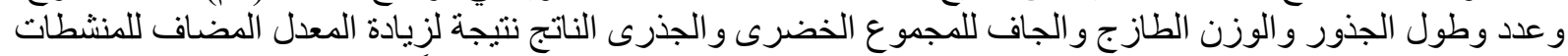

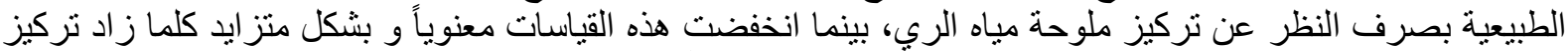

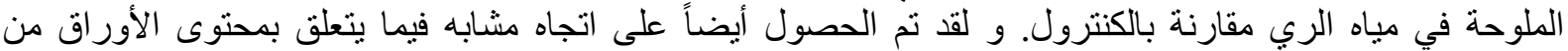

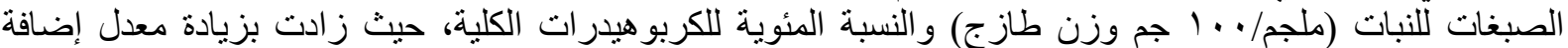

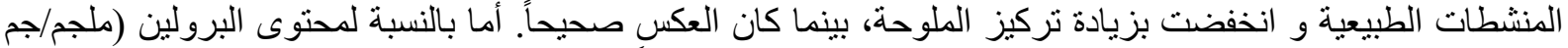

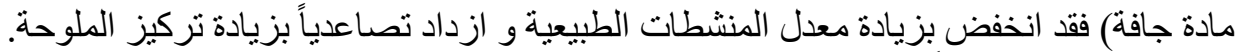

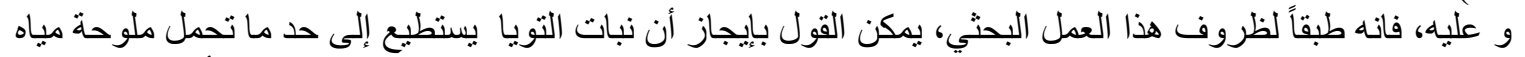

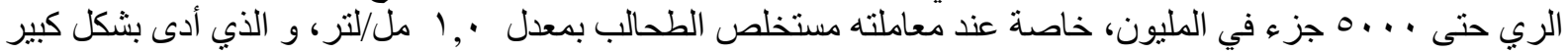

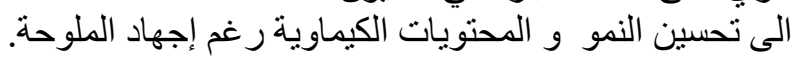

